\title{
Kánonická vizitácia kysáčskej evanjelickej cirkvi z roku 1835
}

\author{
JANKO RAMAČ1 ${ }^{1}$ - DANIELA MARČOKOVÁ2 \\ Oddelenie slovakistiky a Oddelenie rusinistiky Filozofickej fakulty \\ Univerzity v Novom Sade, Srbsko
}

The canonical visitation of the Evangelical Church in Kysač from 1835

\begin{abstract}
In the historiography of Slovaks in Southern Hungary/Yugoslavia/ Serbia, an important place is given to monographs of individual settlements occupied by Slovaks in most or a significant number. The monograph on Kysač describes in detail the process of settling Slovaks, but much more modestly the wider context of their social and political life until the mid-19th century. About this period, a fair amount of data offers Hronika of local Evangelical a. c. Church by the author František Jesenský, but also this resource is underutilized. Also, practically as historical sources about the history of Kysač at the end of the $18^{\text {th }}$ and in the first half of the $19^{\text {th }}$ century, the records of canonical visitations from $1798,1810,1818,1825$ and 1835 remained unknown and unused. The aim of this paper is to, by publishing a record of the canonical visitation from 1835 in both the original Latin and Slovak translation, make available to researchers a resource, which provides a wealth of data from the economic and social life of this national and ecclesial community.
\end{abstract}

Keywords: Slovaks in Southern Hungary, Kysač, Evangelic a. c. Church in Kysač, canonical visitation, school.

DOI: https://doi.org/10.24040/ahn.2020.23.02.105-130

Zápisnice o kánonických vizitáciách ako cirkevné protokoly primárne vznikli pre potreby cirkví. Vyššie cirkevné vrchnosti vykonávajúc kontrolu jednotlivých cirkevných spoločenstiev vo svojej oblasti o tom viedli podrobné zápisnice, ktoré majú prvoradý význam pre cirkevné dejiny. Zvyčajne ponúkajú prvotriedne autentické údaje o stave cirkevných objektov, inventári, o pomeroch vo farnosti, obyvatel'stve a veriacich, o cirkevných služobníkoch, najmä o samotnom kňazovi, o školách a učitel'och, o cintoríne, o cirkevných sviatkoch, často aj o obyčajach

\footnotetext{
${ }^{1}$ Príspevok predstavuje parciálne výsledky v rámci projektu Vojvođanski prostor u kontekstu evropske istorije (17002), ktorý financuje Ministerstvo osvety, vedy a technologického rozvoja Republiky Srbsko.

${ }^{2}$ Príspevok predstavuje parciálne výsledky v rámci projektu Diskurzy menšinových jazykov, literatúr a kultúr v juhovýchodnej a strednej Európe (178017), ktorý financuje Ministerstvo osvety, vedy a technologického rozvoja Republiky Srbsko.
} 
súvisiacich s nimi. Ako vynikajúci historický zdroj zápisnice o kánonických vizitáciách často ponúkajú cenné údaje aj o ekonomických pomeroch, o úrodách a cenách obilia, o prácach na niektorých objektoch, o obyčajoch a živote veriacich, často aj o morálnom živote spoločenstva alebo jednotlivcov a o mnohých iných pomeroch a udalostiach.

Cirkevný zbor v Kysáči bol prvýkrát kánonicky vizitovaný v 18. storočí, v roku 1798, ale tú zápisnicu sa nám doposial' nepodarilo nájst'. ${ }^{3}$ Neskoršie, v prvej polovici 19. storočia, v rokoch 1810, 1818 a 1825, boli kánonicky vizitované evanjelické cirkevné zbory v Báčke a v Srieme, ale $\mathrm{z}$ týchto rokov neboli nájdené zápisnice pre Kysáč. Našt’astie, zápisnice kánonických vizitácií evanjelických cirkevných zborov v Báčke a v Srieme z roku 1835 sú väčšinou zachované. ${ }^{4}$ Zdá sa, že údaje zo zápisníc kánonických vizitácií evanjelických cirkví v Báčke, Srieme a Banáte z roku 1835/1836 sú najviac používané v Dejinách slovenského evanj. a. v. cirkevného sboru v Kovačici Jána Čaploviča. ${ }^{5}$ Ked’že zápisnica kánonickej vizitácie evanjelického cirkevného zboru v Kysáči z roku 1835 nebola doteraz v historiografii použitá, prikladáme ju v preklade z latinského jazyka s nevyhnutnými vysvetlivkami v presvedčení, že budúci bádatelia budú $\mathrm{z}$ tohto zdroja čerpat' údaje pri vypíňaní medzier $\mathrm{v}$ doterajších zisteniach o celkovom spoločenskom a hospodárskom živote Slovákov v Kysáči. ${ }^{6}$

\footnotetext{
${ }^{3}$ Hoci zápisnica o prvej kánonickej vizitácii evanjelického a. v. cirkevného zboru v Kysáči z roku 1798 sa nenašla, niektoré údaje z nej sú zapísané v Pamätnici historických zápisov, starších a novších, o povstaní a d'alšom zvel'ad'ovaní cirkvi, počnúc od r. 1773 F. Jesenského. Táto kronika sa nachádza v Archíve slovenskej evanjelickej a. v. cirkvi v Kysáči. Písaná je prevažne v latinskom jazyku, no niektoré jej časti sú v slovenskom či v nemeckom jazyku. Podrobnejšie údaje nachádzame u Samuela Čelovského (ČELOVSKÝ, Samuel: Podiel osadníkov zo slovenských obcí v Mad’arsku pri osídl'ovaní Kysáča v Báčke od roku 1773. In: Kysáč 1773 - 2013: zborník prác. Zost. V. Valentík, Báčsky Petrovec : Slovenské vydavatel'ské centrum, Matica slovenská v Srbsku; Kysáč : Rada Miestneho spoločenstva, 2013, s. 41 - 52) a u Jána Babiaka (BABIAK, Ján: Začiatky slovenského Kysáča (prvých 25 rokov Slovákov v tejto obci). In: Kysáč 1773 - 2013: zborník prác. Zost. V. Valentík, Báčsky Petrovec : Slovenské vydavatel'ské centrum, Matica slovenská v Srbsku; Kysáč : Rada Miestneho spoločenstva, 2013, s. 52 - 66).

4 Protocolla visitationis Ecclesaorum E[van]g[e]licarum Bacs-Sirmiensium, instituta anno 1835, mensibus Septembri et Octobri. (EOL - Evangélikus Országos Levéltár, Budapest). Dostupné na: https://library.hungaricana.hu/en/view/Banyai_04_1835_Bacs_Szerem/?que ry=kisz\%C3\%A1cs\&pg=0\&layout=s [prístup 23. 8. 2020].

5 ČAPLOVIČ, Ján: Dejiny slovenského evanjelického a. v. cirkevného sboru v Kovačici. Kovačica : SEAVCS, 1928.

${ }^{6}$ Kiszács - Ecclesia Aug. Confess. Addict. Evangelica Kiszacsiensis in Icottu Bács Bodrogiensi sita Slavica. In: Protocolla visitationis Ecclesiarum E[van]g[e]licarum Bacs-Sirmiensium, instituta anno 1835, mensibus Septembri et Octobri. (EOL - Evangélikus Országos Levéltár, Budapest). Dostupné na: https://library.hungaricana.hu/en/view/Banyai_04_ 1835_Bacs_Szerem/?query=kisz\%C3\%A1cs\&pg=0\&layout=s [prístup 23. 8. 2020].
} 
Kysáč sa ako osídlené miesto prvýkrát spomína v roku 1461 pod názvom Alch (Alcs), v roku 1464 ako Kys Alcz a neskoršie, v rokoch 1457 a 1504, ako Nagalcs. ${ }^{7}$ V literatúre sa v samotných začiatkoch prist'ahovania Slovákov do Kysáča vyzdvihuje úloha grófa Anreja Hadíka, ktorý si, pravdepodobne kvôli slovanskému pôvodu, prial svoje Futocké panstvo osídlit’ čím väčším počtom svojich súkmeňovcov. ${ }^{8}$ Michal Vardžík (1736 - 29. 11. 1812) bol prvým Slovákom, ktorý sa roku 1773 prist’ahoval do Kysáča. ${ }^{9}$ Významný historický materiál, ktorý objasňuje lokálne špecifickosti a najmä pôvod Kysáčanov je kronika farára Františka Jesenského, v ktorej sú obsiahnuté vzácne súpisy obyvatel'stva s uvedením mena hlavy rodiny, pôvodnej stolice a obce, ako i roku prist'ahovania. Podl'a tejto Pamätnice intenzívny primárny proces st'ahovania Slovákov do Kysáča prebiehal do konca 18. storočia, v rokoch 1773 - 1798, teda v priebehu jedného štvrt'storočia. Slovenskí osadníci prichádzali z 55 obcí; najviac rodín prišlo z Novohradu, potom z Hontu, z Liptova, z Turca, ako i z Nitrianskej, Zvolenskej, Peštianskej, Békešskej a Tolňanskej stolice, no prichádzali aj z báčských obcí Petrovec, Hložany, Kulpín a Selenča. Na základe vlastných výskumov Čelovský uvádza, že sa do Kysáča prist'ahovalo obyvatel'stvo z 87 rozličných obcí a z 19 stolíc. ${ }^{10}$ Prvá vlna st’ahovania Slovákov do Kysáča trvala desat' rokov s výrazným vrcholom v rokoch $1776-1777$. V tom časovom úseku prišlo asi 90 slovenských rodín, čo bolo viac ako dvojnásobok rodín starousadlíkov - Srbov. ${ }^{11}$ Vydanie Tolerančného patentu roku 1781 podnietilo príchod novej vlny pristahovalcov roku 1783. St'ahovanie dosiahlo vrchol roku 1786, ked’ do Kysáča prišlo až 74 rodín. Podl'a zápisov komisára Báčskej stolice Andreja Virága z roku 1789 v Kysáči bolo 919 Slovákov. Mali svoju školu, ktorá bola súčasne modlitebnica aj fara. Ked'že plocha kysáčskeho chotára bola relatívne malá, nedostatok obrábacej pôdy a vol'ných usadlostí zastavili príchod d'alších slovenských osadníkov. ${ }^{12}$ Posledná väčšia skupina Slovákov, spolu 35 rodín, prišla do tejto obce $\mathrm{v}$ roku 1790 . V poslednom desat'ročí 18. storočia prišli menšie húfy slovenských rodín už iba $\mathrm{v}$ symbolickom počte. ${ }^{13}$ Bez ohl'adu na vel'mi nepriaznivé spoločenské a ekonomické pomery, Slováci evanjelici v Kysáči už v prvých rokoch od začiatku st'ahovania nachádzali silu a spôsob organizovat' sa ako národnostné a náboženské spo-

\footnotetext{
${ }^{7}$ CSÁNKI, Dezső: Magyarorszák történelmi földrajza a Hunyadiak korában, II. Budapest, 1894, s. 142.

${ }^{8}$ BOROVSZKY, Samu: Bács-Bodrog vármegye, I. Budapest, 1909, s. 128.

9 ČELOVSKÝ, S.: Podiel osadníkov zo slovenských obcí, s. 45.

10 ČELOVSKÝ, S.: Podiel osadníkov zo slovenských obcí, s. 47.

${ }^{11}$ BABIAK, J.: Začiatky slovenského Kysáča, s. 56.

12 ČELOVSKÝ, S.: Podiel osadníkov zo slovenských obcí, s. 47.

${ }^{13}$ BABIAK, J.: Začiatky slovenského Kysáča, s. 56.
} 
ločenstvo. Vlastným angažovaním sa a odriekaním zbierali prostriedky do fondu pre založenie školy a cirkvi. Tak bol roku 1799 ustanovený fond pre výstavbu evanjelického chrámu, ked' 52 rodín zozbieralo 206 forintov a 54 grajciarov. ${ }^{14}$

Už letmým porovnaním zápisníc o kánonických vizitáciách Kysáča, Petrovca a Kulpína (z roku 1835) a Kovačice (z roku 1836) bolo možné všimnút' si početné podobnosti, pretože miestnym správcom cirkevných spoločenstiev zo strany vyšších cirkevných vrchností boli zaslané tie isté otázky, na ktoré odpovedali v písomnej forme. Zaznamenané sú aj menšie či väčšie rozdiely v súvislosti s organizovaním cirkevného a školského života spoločenstva $v$ postrehoch, pripomienkach alebo požiadavkách komisie ohl'adom spoločenstva, kňaza alebo učitel'a s ciel'om, aby sa niektoré nedostatky alebo neakceptovatel'né javy a praktiky zlepšili alebo odstránili. Hoci sa odpovedalo na tie isté otázky, zápisnice sa navzájom odlišujú v dížke, pretože kňazi formulovali odpovede rozličným spôsobom. Všetky zápisnice sú písané v latinskom jazyku, ale i tu existujú značné rozdiely, pretože niektorí správcovia cirkevných spoločenstiev lepšie ovládali tento jazyk a iní, napríklad kysáčsky kňaz Juraj Jesenský, o niečo horšie.

Počas prípravy na publikovanie originálneho textu zápisnice o kánonickej vizitácii v Kysáči z roku 1835 sme sa snažili vo všetkom vyhoviet' požiadavkám publikovania pôvodného historického materiálu $\mathrm{s}$ minimálnymi zásahmi v dekódovaní skratiek a s pridávaním nevyhnutných komentárov v poznámkach.

Skratky dekódujeme v hranatých zátvorkách. Obvyklé skratky nebudeme dekódovat', aby sme text dodatočne nezat'ažovali, ale uvedieme, ktoré sú to skratky (zväčša názvy peňažnej meny a jednotiek miery) s uvedením ich plného názvu a významu. Skratky názvov mesiacov sme nedekódovali, ako ani niektoré všeobecne známe skratky napr.: A., a. - annus - rok, N. Testamentum - Novum Testamentum a podobne. Interpunkciu a interpunkčné znamienka, ako i použitie vel'kého začiatočného písmena sme, hoci sa ich použitie môže zdat' nelogické a nedôsledné, neopravovali ani nemenili. Tiež sme nechali originálne zápisy radových čísloviek, ktoré neboli vždy dôsledne písané - kombinované boli rímske a arabské číslice pre niektoré zápisy rokov, arabské číslice pre zapísanie dížky, množstva, objemu, dátumu a roku. Mená osôb a miest sú uvedené $\mathrm{v}$ latinskom origináli a v zátvorke sú zapísané podl'a pravidiel slovenského pravopisu. Pred začiatkom kánonickej vizitácie evanjelických cirkevných spoločenstiev v Báčke, v Srieme a v Banáte roku 1835/1836 každé cirkevné spoločenstvo dostalo od vyššej cirkev-

${ }^{14}$ Arhiv Vojvodine, Fond Bač-bodroška županija, 286a/1778; 1092/1780. 
nej vrchnosti uniformné otázky v latinskom jazyku (ktoré sa nám nepodarilo nájst'), na ktoré mal miestny kňaz odpovedat'. Text tejto zápisnice tvoria odpovede na otázky položené $\mathrm{v}$ písomnej forme, ktoré dával miestny farár Juraj Jesenský. Nachádzajú sa tu aj komentáre a pokyny komisie, ktorá vykonala kánonickú vizitáciu.

Komisia prichádzajúca do každého cirkevného spoločenstva kontrolovala odpovede kňaza a faktický stav na tvári miesta a do zápisnice vnášala mienku o kňazovi, jeho duševno-morálnom charaktere a na konci zápisnice pripomienky alebo eventuálne explicitné nariadenia $\mathrm{s}$ ciel'om nápravy nedostatkov. Obvyklé skratky, ktoré sa často objavujú v texte dekódujeme v hranatých zátvorkách iba pri prvom výskyte, ako napríklad:

ARD, AA RR DD - Admodum Reverendus Dominus, Admodum Reverendi Domini - ctihodný pán/ctihodní páni

a.c., Aug. Con. - Augustaneae Confesionis - augsburského vierovyznania

C.v. - konvencionálna valuta/mena

Dnica - Domenica - nedel'a

D, Dnus. - Dominus - pán

Eccla. - Ecclesia - cirkev, cirkevný zbor

Ev. Egl., Eglic. - Evangelicus, a. - evanjelický

F, flo. - florenus - florén, forint

I., Inc. - Inclytus - slávny

V., Ven., - Venerabilis - vysokoctený

V. D. M. - Verbi Domini Minister - Slova Božieho kazatel' (Služobník Slova Božieho)

$\mathrm{V}$ - valuta - mena

W.W., W.V., v.v. - Viener valute, Wiener wahrtunt, Viener valute viedenskej meny

$\mathrm{Xr}$ - crucifer - grajciar

\section{Kiszács}

Ecclesia Aug[ustaneae] Confess[ionis] Addict[a] Evangelica Kiszacsiensis in I[nclyti] Co[mmi]t[a]tu Bács-Bodrogiensi sita Slavica

1. Origo eiusdem Eccl[esi]ae ab anno 1785 nacta facultatem intertenendi L[udi] Rectorem, dein 1788 etiam Parochum.

2. Vicissitudinibus nullis obnoxia.

3. Numerat animas mater 2060 , filia vero 107 , summatim 2167 ; sexus masculini 1017, sexus sequioris 1150 , confessionis capaces 1118 in utraque, paria coniugum Evangelicorum 489 summatim, mixta nulla habet. Natos 1834 nacta 129 , ac eodem anno in mortuis amisis 69; copulati sunt 38 . Cum anno praefato 70 catechumenos 30 e 
sexu mascul[ini], 40 sexus sequior[is] instituissem, anno decurenti institutionem ideo missam feci, quod nullae proles idoneae adfuerint.

4. Templum longitudinis 10 orgiarum, latitudinis vero $5-1$ pedis et 6 pollicum. In parte anteriori formae quadratae, in posteriori ovalis, ex tegulis ustis, 1795. 29 Junii aedificari coeptum et cum turri 1799. sub initium Junii finitum. Anno 1816 imbricibus tectum et 1834 diebus Aug[usti] et Septembris reparatum unaque ab intus et extus dealbatum. In Templo videtur Sacra Cathedra, super mensam arae intra duas columnas marmorisata; altare ex tegulis, duas super mensam columnas habens; baptisterium ex tegulis ad dextram arae partem, operculo et patinula provisum laminea; chorus absque organo, quo nos cum tempore providebimus; sellis ex ligno abietino gaudemus; inscriptionibus autem in templo nullis.

5. Clenodia Ecclesiae. Calices duo, alter stanneus, unius sextarii, ${ }^{15}$ cum inscriptione: Eccl[esi]a Kiszacs curavit sz; alter a[nno] 1811 emtus, cuius poculum unius sextarii argenteum inauratum; patella laminea, at bene inaurata; ciboria pixis laminea; canthari duo laminei; patina laminea, candellabra quatuor lignea; muntilia quinque, horum duo sericea; tegumenta altaris aeque quinque, duo peneque ex his sericea, cum fimbriis denticulatis unum; alba una, ferramenta duo pro hostiis pinsendis; Biblia; Thesaurus precum Jacobaei, Meditationes Kreuzbergi; Tranoscius; Agenda slavica seu rectius Rituale; Crucifixum per Perill[ustrem] D[omi]num V[ice] Insp[ectorem] Ven[erabilis] Senioratus Bács-Sirmiensis Samuelem Parwy de Czécze donatum; Sigillum 1818 emtum, cujus in margine degitur: Sigillum Ecclae Eglicae A. C. Kiszács, in medio corona et citatio haec 1 Thess. v. 12.

6. Turris 1816 altius elevata et lamine tecta. Muro eiusdem, lapis marmoreus ex Comitatu Komaromiensi Possessione Marmor Süttö 1801 allatus impositusque 1802 in Junio cum sequenti inscriptione autore Parocho Francisco Jeszenszky

EXCIta

SCeptra FranCIsCo patrlae tenente

GaLLICo strages popULo CIente

Peste trans IstrUM stIgIo fUrente

sUrreXI

GaLLUs teLa VIbrans tUrres DUM Verberat aLtas

KIszács In VILI sUrgIt tIbI tUrrIs, arena

StrassnI Mor Wten čas k WLasti se zbLIžUge

ZbItečné žItI sUChota zbraňUge

\footnotetext{
15 Pravdepodobne ide o 1 pintu, starú uhorskú mieru, ktorá v prvej polovici 19. storočia v prepočítanej hodnote merala dve holby, t. j. 1,66 litra.
} 
Franka UkrUtnost krWe ňestanVge

kDIž kIsač toto staWenI WzbUzUge.

Campanae tres, prima librarum 84 cum inscriptione: Feri Brunner goss mich in Offen 1787; altera emta 1801 librarum 276 cum inscriptione: Eccla Eglica Aug. Conf. Kiszacsiensis, curavit sub Rev. Parocho Franc. Jeszenszky an. MDCCCI, supperius: gegossen in Pest von Heinrich Eberhard; tertia comparata annno 1802, librarum 492, cum Inscriptione: In usus suos curavit Ecclesia Evangelica Aug. Conf. Kiszacsiensis MDCCCII, superius: gegossen in Pest von Heinrich Eberhard.

7. Proventus Eccle[si]ae Colliguntur ex tintinabulo; offertoriis utpote: Festo Novi Anni, D[ome]nica Trinitatis, D[ome]nica post Festum Petri Pauli, D[ome]nica Eucharistica, D[ome]nica post feriam omnium sanctorum et D[ome]nica 1.a Adventus; oblationibus benevolis; ex pulsu funebri, sed praeprimis ex adrepartita annue in autumno praestanda avena; quodvis par praestat $1 / 3$ pestanae Met[retae] totidem aeque a quovis quadrante collonicalis sessionis. Dominium I[nclytum] praeter 5 orgias lignorum focalium annue Eccl[esi]ae nil praestat. Tenuta seu latifundia nulla possidet Eccl[esi]a.

Duas cassas Eccl[esi]a habet. Maior me svasore 1829 enata et exclusive in usum templi devota; ex minori Parochus, L[udi] Rector et Aeditui salarisantur. Licet ex priori, anno transacto in Autumno, in reparationem templi 965 f. 36 xr. expenderimus, tamen capitali activo 4152 f. W. gaudemus. Fructificat pecunia haec apud Ecclesianos Kiszacsien[si]bus legale interusurium ferendo, neque obtinet quispiam ex summa illa, in fidejussorem habeat in obligatorialibus subscriptum. Hucdum nil perditum nec periclitatur pecunia elocata, cum exiguae summae et omnino a proportione virium et latifundiorum petentis seu summentis distribuatur. Minoris Veteris casse perceptionis summa 1834 effecit 988 et $37 \mathrm{~W}$, erogationis vero 772 f. $44 \mathrm{xr}$ W., adeoque status cassae in $215 \mathrm{f}$. V. et $53 \mathrm{xr}$. mansit.

Cassa maior ex praeattacta avena exsurgens administratur per Andream Orgowany colonum Kiszacsiensem, qui ex summis elocatis 1a D[ome]nica Adventus aut paulo serius rationes presbyterio convocato praestat; posterior per curatorem, aeditum et loc[alis] Parochum, quoque, illo eodem tempore revidetur, ita quidem, ut notarius localis perceptionis et erogationis summas computet secundum usum receptum. Cassa minor conservatur in aedibus parochialibus, a Cistula clavibus curatore et aedituo habentibus. Influxus in rem pecuniariam Parochi consistit in eo, quod summulas per aeditus latas aut vero extradatas adnotet accurate.

Lites nullas habet. 


\section{Janko Ramač - Daniela Marčoková}

8. Libri Ecclesiae. Biblia cum N[ovo] Testamento, Thesaurus preccum Jacobaei, Meditationes Kreuzbergi, Tranoscius, Postilla Blahiana, Agenda slavica, rectius Rituale.

a. Documenta habet: Copian Intimati, quoad inducendum L[udi] Rectorem et quoad aedificandum templum.

b. Matricam in uno volumine Baptisatorum, Copulatorum et Mortuorum ab Anno 1787 dein vicissim Matricam Baptisatorum ab Anno 1823 et denique matricas punctim Copulatorum et Mortuorum ab Anno 1832.

c. Protocollum Eccl[esi]ae Intimatorum, currentalium, conventuum.

d. Libri supraattacti et insuper Nowý modlitebny poklad od P. Ondrege Palumbiniho.

e. Inventarium nullum.

f. Coemeterium est versus occidentem prope pagum vetus et novum, utrumque fossato cinctum, eorundem area singillative efficit 150 orgias $\square$, recentius ab Anno 1820 emetitum, cujus usum capit Parochus.

B. Filia Neo Piros lias Remanentia, cum Matri omnino advicinet, nullum oratorium nullamque Scholam habet. Ex Matre ante quinquenium eo emigrarunt, ad eamque Spiritualis solatii capiendi gratia veniunt, imo et cadavera mortuorum ad coemeterium Matris deducunt. Licet tantisper isolati, tamen competentias suas rite pendunt et Matrem pro posse sublevant.

\section{Directio Eccl[esi]ae politico Oeconomica}

Inspectorem Eccl[esi]a non habet; Conventus aut in Parochia aut vero in Schola per Parochum indicti habentur; Rationum censuram peragit Loc[alis] Notarius 1-a D[ome]nica Adv[tus] aut serius Presbyterio convocato Curator Georgius Bartko et Aeditus Joannes Ferko a biennio officio defunguntur, instructione provisi et adiurati sunt. In officii admonentur, pecunias incassant; et quantum necesse est laboribus Parochialibus et Scholasticis circa campestria attendunt. Renumeratio eorum: proventus ex tribus offertoriis, secunda feria Nat[ali], Paschali et Pentecostali; unum par calceorum, quibus me suadente addita subductura et braccae resolutae, immunitas a portionali quanto et laboribus cuiscunque generis $\mathrm{Co}[\mathrm{mmi}] \mathrm{t}[\mathrm{a}]$ tensibus et domesticis.

Presbyterium efficiunt selecti ac adiurati homines, eorum officium est, dum per Parochum Conventus indicuntur comparere, et de is maturo judicio discutere, quae bonum et florem Eccl[esi]ae provehunt.

\section{Status Ecclae internus moralis religiosus}

Templum selose frequentant, crebrius vero hiemis ac aestivo tempore. Dies domenicae laboribus minime profanantur, et talibus aut festis quibuscunque judex ex officiose in diversorio constituitur, qui juventutem caligine vespertina prodeunte domum abire jubet. Notorie 
Contemtores cultus divini nulli sunt. Indifferentes erga $\mathrm{D}$ [omini] Coenam aeque nulli. Lecturae et Scripturae paucissimis senibus exceptis ommes gnari. Liberi ad Scholam diligenter mituntur; transacto anno 257 frequentarunt Scholam.

Libros non solum sacros, verum et argumenti varii sibi comparant. Testimonio est autumnus anni praeteriti, quo ex Čitankis per Venerab[ilem] Kollár 100 Ex[emplaria] Submissis, actu vel 40 ex[emplaria] distraxerim.

Sunt compti et satis urbani -- at proh! Aliqui vinolentiae dediti. A decursu 15 annorum nonnisi una proles spuria nata.

Circa emendandos notorice peccantes observatur regula Christi Math. XVIII rarissime influit Magistratus civilis.

Matrimonia arbitrarie soluta sunt duo.

In carceribus publicis ex Eccl[esia] Kiszács nulli genuunt.

Superstitiosi non sunt.

Zelo beneficiendi sunt percisi.

IV. Primus Parochus apud Kiszacsienses erat Michael Szlamay ab anno 1788 usque 1794-um, qui ob ebullientem Parocho omnino inconvenientem affectum (:casus calamus vetat prolixiorem enarationem:) amotus Bajsae Sacram Cathedram nactus.

Secundus Parochus venit legitime vocatus 1794 ex Eccl[esi]a Tót Sztamoriensi ${ }^{16}$ A.R.D. Franciscus Jeszensky de Ead VIR de Eccl[esi]a Kiszács omnino meritissimus, prius Dec[anus]. J[nclyti] Ven[erabilis] Senioratus Bacs Sirmiensi dein Ord[inarius] Notarius. Eodem Rectore templum cum turri exstructum, campanae duae maiores emptae, domus usibus ad Rectorum destinata, reparata, nova sedes parochialis ferme perfecta, complura protocolla Ecclesiastica conscripta diligenter. Mortus praemature 11. Nov[embris] 1805 anno.

Tertius Parochus erat A.R.D. Michael Laukonides, qui Szarvaszini apud Reverendissimum ac Amplissimum D[omi]num Hamaliar Capellanus, provocationi Kiszacsiensium assurexit a. 1806. 29. Febr[uarii] comparuit. Et hic vir assiduitate SUA multum contulit ad florem Eccl[esi]ae, et enim turris 1816 est ellevata, horologium structum serius eodem Rectore. Anno 1827 mortuus 28-a Junii apoplexia tactus, qua emeritus senior I[nslytum] ac V[enerabilem] Senioratus Bacs-Szirmiensi.

Quartus sum ego Georgius Jeszenszky 15 II 1799 parentibus R. D. Francisco Jeszensky de Ead[em] ${ }^{17}$ et Catharina Fabry in Kiszács natus.

\footnotetext{
16 Tótsztamora - dnes Stamora Germană - obec v Rumunsku v Tamišskom okrese. V obci najprv žili Slováci a neskoršie, koncom 18. storočia sa tu usídlili aj Nemci.

${ }^{17}$ František Jesenský pochádzal z Vel'kého Jasena (de Nagy-Jeszen) v Turčianskej župe. ČAPLOVIČ, J.: Dejiny slovenského evanjelického a. v. cirkevného sboru, s. 31.
} 
Humaniora MBerinii ${ }^{18}$ audivi, dein septennium Posonii transegi. Filosofico-theologicis studiis 1824 finitis ex pulveribus praefati Lycei veni eodem anno ad pulveres denuo NVerbaszinum, ${ }^{19}$ electus eram per I[nclytum]ac. Ven[erabilem] Senioratum Bacs-Sirmiensem pro Professore Scholae Gramaticalis. Cathedre musagetarum tenellorum praefui duobus annis ii 1824/25 et 1825/26 at hanc Cathedra musis sacram communicavi cum aeque sacra Kuczuriensi Ecclesiastica, posteaquam praevii ordinibus sacris per R[everen]diss[im]um ac amplissimum $\mathrm{D}$ [omi]num Adamum Lovich redimitus fuissem. In Kuczura sesquialterum annum exegi, dein fatisfuncto A.RD. Michaele Laukonides provocationi Kiszacsiensium assurexi; in Kiszacs Dei gratia ab Octennio officio ministri defungor.

Linguas calleo praeter latinam, slavicam, germanicam, illiricam, valachicam, et magyaricam.

\section{A. Muneris Sacri Administratio}

1. Conciones scribuntur.

In concionibus auditores fidelitatis erga principem et Magistratui testandae obedientiae admonentur.

2. Catechisationes aestivae a 1-a: Trinit[atis] usque mens[is] Decemb[ris] (secund[um] Herderum) habentur, sed nimis negligenter frequentarunt praeprimis anno Cur[ente]. Catechumeni tempore Quadragesimae instituuntur et die Viridium solenniter confirmantur. Neogamorum institutio in Kiszacs ab octennio est in usu, ut id quod neglectum est private in parochiae institutione compensatur.

3. Cultus Divinus dominicalis peragitur secundum Rituale seu morem in Eccles[sias]. Ev[angelicis] Slavicis V[enerabilis] Senioratus receptum; in liturgicis nihil additum nihil denitum. Quotidianus cultus habetur cum praelectione.

4. Neonati baptizantur publice in precibus praesente populo vel diebus solis. Sacra D[omi]ni Coena propinatur: Festo N[ovi] Anni Nativitatis, Paschatos, Pentecost[alis], Joannis et Michaelis interuptim et 4 vel 5 dominicis pro ratione venientium.

5. Morbidorum provisio et Spiritalis et Physica fit, medicus si necessum advehitur et insicionem variolarum sibi commendatam habet praeferenter.

6. Scholam inexpectatus visitare soleo saepissime ut calcar addam L[udi] Rectori - consiliorum sanorum acceptandorum capaci.

\footnotetext{
${ }^{18}$ Mezőberény (slov. Pol'ný Berinčok) - mesto v Mad’arsku v Békešskej župe.

${ }^{19}$ Neu Verbas/Nový Vrbas - dnes Vrbas vo Vojvodine, v Srbsku. 
7. Nonnisi maturae aetatis postquam tribus distinctis vicibus secundum $\mathrm{B}$ [enigni] Patentale promulgati fuissent, observata jurisjurandi formula, matrimonio junguntur.

8. Cadavera mortuorum ante 48 horas non efferuntur nisi in casibus dispensatis.

9. Matricae, protocolla, rationes accurate ducuntur.

B. Character moralis. Vir parum doctus, sed superbus. Pastor negligens; graviter se prehensus.

C. Bibliotheca: pulveribus tecta.

D. Habitatio. Anno 1806 aedificium parochiale tribus cubilibus et camera fructum haud commodum, at neros intendemus ut commodius nanciscamur.

E. Proventus V[erbi] D[omini] Ministri.

1. In fixo singulum par coniugatum solvit $20 \mathrm{xr}$ in con. $\mathrm{m}$.

2. Tritico terra collonicali gaudentes et domiciliati unam tertiam metretae pestanae.

Subinquilini in tritico medietatem praestant at in pecunia $20 \mathrm{x} . \mathrm{c.m}$.

3. Media sessio cultivatur una cum prato et horto per Ecclesianos.

4. Quatuor currus foeni.

5. Ab introductione puerperae $18 \times$ c.m.

6. A copula $1 \mathrm{f}$ c.m., a promulgatione $10 \mathrm{x}$ c.m., introductione sponsae $18 \times$ c.m., assatura vini media.

7. A funera minori 18 x c.m., a maiori cum sermone 1 f. c.m.

8. Numus confessorius - hujus sextalitas est Rectoris et tria offertoria feriis anniversariis, ex quibus tertiam partem accipit L[udi] Rector.

9. Colleda, tertialitem hujus obtinet Rector.

10. Ligna focalia orgiae sex.

11. Commolitio frugum.

12. Currus necessarii s[ancta] vectura.

13. A singula domo pullum.

Accurate et bono ordini asveti rite dependunt competentias imo et plus una vel etiam duabus orgiis lignorum. Contractus transactione est melioratus 19. Dec[embris] 1803. Agri attamen melius cultivari possent, sunt vallati.

V Scholae.

A. Scholae Rector est Samuel Mitralovits annorum 21 antea Palankae per trium mensium temporis spatium, dein in Kulpin duobus annis, nunc vero apud nos a duobus mensibus L. Rector. Studuit $\mathrm{N}[\mathrm{eo}]$ Verbaszini et MBerinii.

a. Juvenis bonos mores praesefert - et est omnino obsequiosus. 
b. Hoc mense Septembris prima vice apud nos proles instituere inchoovit, quali vero successu effectus docebit. Bell-Lankasterianam Methodum sequi debebit - crescente numero scholarium.

B. N[ume]rus discipulorum 1834/5 scholam frequentantium effecit 257.

C. Proles ultra 12-um annorum frequentare solent et debent in Kiszacs. 1-a Septembris conveniunt et mense Junio dimituntur.

c. Objecta doctrinalia, praeter lecturam, scripturam, cantum, catechesim, tractatur physica, historia naturalis, geografia, catechesis sanitatis, historia biblica et arithmetica.

d. Utitur praeter alios plures libros et Čitanka.

D. Aedificium scholasticum una cum habitatione L[udi] Rectoris est commodum.

E. Proventus L[udi] Rectoris sunt sequentes:

1. In fixo a pari coniugato accepit $15 \mathrm{xr}$. walut. et medietatem unius sic dictae vecae, ${ }^{20}$ ab iis, qui terras possident ac domiciliati sunt; a subinquilinis vero sextalitatem seu portionem vulgo - unius Pest[inae] M[etretae].

2. Quadrans sessionis cultivatur ab Ecclesianis, non absimiliter etiam hortus.

3. Duae orgiae lignorum quercinorum.

4. A quavis prole Scholam frequentante $15 \times \mathrm{V}$. V.

5. Gregorisatio, Blaseatio, farinatio et hostiatio.

6. A minori funere $18 \mathrm{x}$ W. a maiori cum carmine $30 \mathrm{x}$.

7. Currus necessarios.

8. Commolitionem frugum pro domestica necessitate.

9. Ex offertoriis 3-um festorum anniversariorum tertiam partem

10. Ex nummo confessario sextalitatem.

11. Ex Colleda tertiam partem.

Didactra haud accurate solvuntur.

F. Fundatio pro Schola eadem, quae pro templo.

G. Inspector Scholae est localis Parochus.

H. Libri Scholastici: Historia Hübneri, Biblia cum N[ovo] Testamento, Tranoscius, 2 Ex[emplaria] Čitankae

I. A.R.D. Decanus praescribere solet seriem lectionum seu rectius obiecta scholaribus doctrinalia proponenda.

VI Obstetrices due adiuratae, formulam baptismi norunt officiisque admonentur. Solutio eorum libo panis et 6 grossi $^{21} \mathrm{~W}$.

\footnotetext{
${ }^{20}$ Veka - štvrtina peštianskej merice.

21 Gross (groš) - rakúsko-uhorská drobná minca nazývaná aj grajciar, päták, šesták, desat'haliernik, dvadsat'haliernik; peniaz malej hodnoty.
} 
VII Vespillo una et campanator in aede per Eccl[esi]am aedificata ab omnibus praestationibus libera degit. Foveas justae profunditatis parat. Salarium eius 19 metretae Pestinae et a quovis pari grossus. Pati mortui infantes sepeliuntur in coemeterio. Idem fieret si autochires ex morbo quod Deus avertat, reperirentur.

VIII Instituta caritativa nulla. Hospitia pro vidualibus R[everendorum] D[ominorum] Ministrorum et L[udi] Rectorum nulla.

IX Annua devotiones

Sermo eucharisticus post messem esse solet.

Memoria Nativitatis regnantis Principis cum sermone celebratur.

Dominica post 1.-a Novembr[is] sermo inauguralis judicum est in usu, qua occasione, judex cum juratis adiurantur.

$\mathbf{X}$ Postulata et gravamina

1. Ex parte Ecclesiae.

2. Ex parte V[erbi] D[omini] Ministri - commodiorem habitationem anhelarem.

3. Ex parte L[udi] Rectoris, si didactra in fixum mutantur.

XI Abusus abrogandi proponuntur

1. Nocturna festo Natalitiorum Jesu Christi sacra non sunt in usu.

2. Turpissima bachanalia ultioris tribus diebus etiam pridem abolita.

3. Balneatio festo Paschatos proh! Viget.

4. Comessationes profussae encaeniorum tempore apud nos minime instituuntur.

5. Convivia baptismalia vigent, nuptalia et quadriduo durant, silicernia aeque in usu sunt.

6. Conciones funerales nonnisi iis dicuntur qui iam confirmati vel Sacrae D[omi]ni Coenae participes redditi; tecto sarcofago vero funera duci solent.

Conscripsit Georgius Jeszenszky Ecclesiae Augustano Evangelicae Kiszacsiensis V[erbi] D[omini] Minister die 30 Septembris 1835.

Peracta die 30. Septembris 1835 Ecclesiae Evang[elicae] Kiszacsiensis Canonica Visitatione per Reverendissimum et Amplissimum Dominum Joannem Szeberínyi, Montanum Superintendantem, praesentibus: Venerabili D[omini] Seniore Joanne Sztehlo, AA RR. item DD. Daniele Kolenyi, Joanne Rohonyi, Ludovico Musculy atque Joanne Scultety, Notario, denique Peril[ustri] D[omini]Conv[entus] Assessore Martino Mártonfy sequentia pro stricto observamine inculcata sunt:

1. Pro Catechisationibus adolescentes aeque ac puelle in futurum diligentius compareant, in qua institutione Ministro Catechesis Herderi pro filo commendata est. 


$$
\text { Janko Ramač - Daniela Marčoková }
$$

2. Calix argenteus inscriptione Ecclesiae et anni, quo paratus est, provideatur; pro morbidis autem alter minor comparetur.

3. Hostie ex nobiliori farina parentur.

4. Pixis laminea purius conservetur, immo alia stanno adminus obducta comparetur.

5. Canthari aeque novi stanei pro vino asservando procurentur.

6. Biblia atque duo attrita Protocolla novis membranis provideantur.

7. Ecclesiani moniti, ut a Cantationibus F. Natalitiorum sub fenestris posthac abstineant; Balneatio autem F[esto] Paschatos penitus est inhibitur.

8. Penes Convivia baptismalia, nuptialia et silicernia moderatio commendata est.

9. Visitatione peracta praesentibus pluribus qui Actui Visitationis interfuere, Reverendissimus Dominus Superintendens accerbissimum dolorem suum palam manifestavit, tum quod Ecclesiam non, uti oporteret, constitutam repererit, et inprimis juventutem in doctrina religionis nimis neglectam observavit, tum quod ob officium debite actum a V[erbi] D[omini] Ministro inhumanitatem et laesionem expertus fuerit.

Sign[atum] In Kiszács die 30-a Septembris 1835.

Joannes Sztehlo Evangelicorum A[ugustinae] C[onfessionis] BácsSirmiensium h[ujus] t[empore] Senior

Joannes Scultety, Incl[yti] et Vener[abilis] Senioratus A[ugustinae] $\mathrm{C}$ [onfessionis] Bács-Sirmiensis, una et huius Canonice Visitationis Notarius

Joannes Szeberinyi Montanus Superintendens

«Kysáč

Slovenská cirkev augsburského evanjelického vierovyznania v Kysáči, v Báč-bodrožskej stolici

1. Za začiatok tejto cirkvi možno považovat' povolenie o uvádzaní učitel'a roku 1785 a potom i farára roku 1788.

2. Niet nijakých zmien. ${ }^{22}$

3. Matkocirkev počíta 2060 duší a fília 107, spolu 2167 duší. Z toho mužov 1017, žien 1150, už konfirmovaných 1118 oboch pohlaví. Manželských párov evanjelikov bolo 489, zmiešaných manželstiev niet. Roku 1834 narodených 129 a v tom istom roku zomrelo 69; sobášených 38 párov. $V$ tomto roku 70 konfirmandov: 30 mužských, 40 ženských. $V$

\footnotetext{
22 Predpokladáme, že sa pod tým bodom vyžadovala odpoved', či od poslednej kánonickej vizitácie boli zmeny na mieste farára $\mathrm{v}$ cirkevnom zbore.
} 
bežnom roku som tiež vykonal konfirmáciu a ani jedno diet’a schopné konfirmácie nevystalo.

4. Chrám dlhý 10 siah, široký 5 [siah], 1 stopu a 6 palcov. ${ }^{23} \mathrm{Z}$ prednej strany štvorcového tvaru, zo zadnej oválneho, vybudovaný je z pečených tehál. S výstavbou sa začalo 29. júna 1795 a zakončený je stavaním veže začiatkom júna roku 1799. Chrám bol roku 1816 pokrytý škridlami a roku $1834 \mathrm{v}$ auguste a v septembri bol vynovený a olíčený zvnútra a zvonku. V chráme je svätá kazatel'ňa nad bohoslužobným stolom medzi dvoma mramorom obloženými stípmi. Oltár je z tehál, a nad ním sú dva stípy. Krstitel'nica je tiež z tehál z pravej strany oltára, má plechový kryt a plechovú konvicu. Na chóre nie je organ, ale ho v dohl'adnej dobe zadovážime, máme lavice z jedl'ového dreva. $V$ chráme nie sú žiadne nápisy.

5. Cirkevný inventár. Dva kalichy, jeden je cínový, kupa objemu jednej šestiny miery ${ }^{24}$ s nápisom: Cirkev Kysáčc, zadovážil SZ; druhý kalich kúpený roku 1811, objemu tiež jednej šestiny z pozláteného striebra; plechová obetná miska pekne pozlátená; cibórium plechové; ${ }^{25}$ dve plechové konvice, plechová miska; štyri drevené svietniky; pät' obrúskov, z ktorých sú dva hodvábne; pätoro oltárnych prestieradiel, z toho dve hodvábne prestieradlá so strapcovými a ozubenými okrajmi; jedna alba; ${ }^{26}$ dve kovové krájadlá na krájanie oblátok; Biblia; Kniha modlitieb Jakubových; Kreuzbergove meditácie, Tranoscius; slovenská Chrámová agenda; krucifix - dar od velebného pána, viceinšpektora Báčskosriemskeho seniorátu vysokodôstojného Samuela Parwyho de Čeče. Pečiatka z roku 1818, na okraji ktorej je napísané: Pečiatka cirkvi A. $V$. Kysáč, v strede koruna a citát: 1 . Sol, 12.

6. Veža nadstavaná roku 1816 a pokrytá plechom, na jej stene mramorový kameň z Komárňanskej stolice z dediny Süttő donesený roku 1801 a položený roku 1802 v júni s nasledujúcim nápisom autora kňaza Františka Jesenského:

Ked' František držal žezlo vlasti

a francúzske vpády otriasali l'udom

(iný preklad: a francúzske vpády volali l’ud do zbrane)

a strašný mor spoza Dunaja prišiel

bola som postavená.

\footnotetext{
${ }^{23}$ Siaha bola stará uhorská miera pre dížku a predstavovala zhruba 1,9 metra (alebo 6 viedenských stôp); 1 stopa $-32 \mathrm{~cm} ; 1$ palec $-2,6 \mathrm{~cm}$. V presne prepočítanej hodnote bol chrám dlhý $19 \mathrm{~m}$ a široký $9,5 \mathrm{~m}$ a 47, $6 \mathrm{~cm}$.

${ }^{24}$ Pravdepodobne ide o 1 pintu, starú uhorskú mieru, ktorá v prvej polovici 19. storočia obsahovala dve holby, t. j. 1,66 litra.

${ }^{25}$ Nádoba na oblátky k Večeri Pánovej.

${ }^{26}$ Kňazovo bohoslužobné biele rúcho, kamža.
} 
Janko Ramač - Daniela Marčoková

Aby zrel blížiacich sa Francúzov

vysokú si bdelý Kysáč postavil vežu. ${ }^{27}$

Má tri zvony: prvý má 84 libier, ${ }^{28}$ s nápisom: Feri Bruner ma odlial $v$ Budíne roku 1787; druhý kúpený roku 1801 má 276 libier s nápisom: Cirkev evanjelická A. V. Kysáč zadovážila počas farára Františka Jesenského roku 1801 a nad tým píše: V Pešti odlial Heinrich Eberhard. Tretí je kúpený roku 1802; má 492 libier, s nápisom: Pre vlastné použitie zadovážila cirkev evenjelická $A$. V. Kysáč roku 1802 a nad tým píše: $V$ Pešti odlial Heinrich Eberhard.

7. Cirkevné dôchodky sa zbierajú zo zvončeka; od darov najmä na Nový rok, v nedel'u Svätej Trojice, v nedel'u po sviatku Petra a Pavla, v nedel'u Eucharistie, v nedel'u po sviatku Všechsvätých a v prvú nedel'u adventu; ako dobrovol'né príspevky; zo zvonenia pre nebohých, a predovšetkým $\mathrm{v}$ jeseň $\mathrm{z}$ ročných dávok $\mathrm{v}$ ovse: každý manželský pár dáva jednu tretinu peštianskej merice, ${ }^{29}$ tak isto aj každý, kto používa štvrtinu sesie. ${ }^{30}$ Zemepán dáva cirkvi iba pät' siah dreva na kúrenie ročne a nič viac. Vlastných pozemkov a majetkov cirkev nemá.

Cirkev má dve kasy. Väčšia, ktorá je zadovážená podl’a môjho návrhu roku 1829, určená je výlučne pre použitie v cirkvi. Z menšej sa vyplácajú farár, učitel' a kostolník. $\mathrm{V}$ minulom roku v jeseň sme z prvej pre renovovanie chrámu strovili 965 forintov $^{31}$ a 36 grajciarov a máme v kase 4152 forintov W. ${ }^{32}$ „Oplodňuje“ sa peniaz tento u veriacich Kysáčanov legálnymi úrokmi. Nikto nedostáva z tejto sumy, kým nepodpíše obligáciu ako záruku. Doposial' sa nič nestratilo, neriskujú sa vybrané peniaze, pretože sú požičané sumy malé a iba podl'a možnosti a vlastníctva pôdy tých, ktorí sa pôžičky dožadujú. V menšej, staršej, kase sme roku 1834 mali príjmy 988 forintov a 37 grajciarov viedenskej meny a výdavkov bolo 772 forintov a 44 grajciarov viedenskej meny, takže v kase zostalo 215 forintov a 53 grajciarov.

Vel'kú kasu, ktorá sa plní od spomenutého ovsa, vedie Andrej Orgován, sedliak Kysáčan, ktorý v prvú nedel'u adventu alebo trochu neskoršie okolo tohto sviatku, ked' sa zvolá presbytérium, podáva správu spo-

\footnotetext{
27 Preklad je prevzatý od S. Čelovského (ČELOVSKÝ, Samuel: Najstaršia epigrafická pamiatka Slovákov v Srbsku. In: Z kultúrnych dejín Slovákov vo Vojvodine. Báčsky Petrovec : MOMS, 2010, s. 341).

${ }^{28}$ Libra/viedenský funt $-0,56 \mathrm{~kg}$.

${ }^{29}$ Peštianska merica - 94 litov.

${ }^{30}$ Sesia v Báč-bodrožskej župe vynášala 32 jutár ornej pôdy a 22 jutár pasienkov, počítajúc jutro pasienkov a jedno jutro intravilánu, počítajúc, že 1 uhorské jutro pôdy I. triedy v Báčke vynášalo 1100 štvorcových siah.

311 forint $=60$ grajciarov (od r. $1780-$ do r. 1876).

$32 \mathrm{~W} /$ Wiener wahrung - viedenskej meny.
} 
lu s kostolníkom, kurátorom a miestnym farárom. Miestny notár potom prepočituje príjmy a výdavky podl'a platných predpisov. Menšia kasa sa uschováva na fare v krabici, od ktorej kl'úče majú kurátor a kostolník. Kňaz má na otázku peňazí iba taký vplyv, že presne zaznamenáva malé sumy, ktoré kostolník vkladá alebo berie z kasy.

[Cirkevný zbor] nemá súdne spory.

8. Cirkevné knihy: Biblia s Novým zákonom, Kniha modlitieb Jakubových, Kreuzbergove meditácie, Tranoscius, Postilla Blahiana, ${ }^{33}$ slovenská Chrámová agenda.

a. Uschováva nasledujúce dokumenty: Kópiu intimátu o uvedení učitel'a a výstavbe chrámu.

b. Matriku pokrstených, sobášených a zosnulých v jednom zväzku z roku 1787 a d'alej od roku 1823 osobitne matriku pokrstených a po tomto osobitne matriky zosobášených a zosnulých od roku 1832.

c. Protokol cirkevných intimátov, cirkulárov a konventov.

d. Horespomenuté knihy a okrem toho Nowý modlitelný poklad od P. Ondreje Palumbiniho.

e. Inventár nijaký.

f. Cintorín je pri obci zo západnej strany starý a nový je zo všetkých strán obkolesený priekopou, povrch každého osobitne vynáša 150 štvorcových siah. Novší, v roku 1820 vymeraný, jeho použitie začal farár.

B. Fília Novi Piroš, inak Remanencija, v susedstve je s matkocirkvou, nemá ani cirkev, ani školu. Z matkocirkvi sa tam pred piatimi rokmi odst'ahovali, ale prichádzajú do nej, aby si ukojili duchovné potreby a aj telá nebožtíkov donášajú na hrobitov matkocirkvi. Hoci sú doteraz izolovaní, predsa svoje povinnosti poctivo vykonávajú a matkocirkev podl'a možnosti podporujú.

II. Správa cirkvi politicko-ekonomická

Cirkev nemá inšpektora. Konvent, ktorý zvoláva farár, usporadúvajú bud' na fare, alebo v škole. Prehliadku účtov vykonáva lokálny notár. V prvú nedel'u adventu alebo neskoršie, ked' sa zvolá presbyterstvo, kurátor Ďuro Brtka a kostolník Ján Ferko, ktorí na dva roky vykonávajú funkciu a zložili prísahu, podávajú správu. Vo vykonávaní práce sa povzbudzujú, peniaze inkasujú a nakol'ko je potrebné, práce na fare, v škole a v okolí vykonávajú. Ich úlohou je podávat' rekapituláciu: príjmy $\mathrm{z}$ troch zdrojov milodarov: v druhú nedel'u Vianoc, na Vel'kú noc a Turí-

\footnotetext{
${ }^{33}$ Matúš Blaho: Nábožné kázaní na všechny neděle a svátky celého roku cirkvi 1 - 2, Levoča 1828, 1829 (PETRÍK, Borislav - RYBÁR, Peter (eds.): Evanjelická encyklopédia Slovenska. Bratislava : BoPo, 2001, s. 272).
} 
ce. Dostávajú pár topánok a na môj návrh rozhodnuté je, aby sa k tomu pridali kožuch a nohavice. Okrem toho, oslobodení sú od dane a všetkých druhov stoličného a panského robotovania.

Presbyterstvo pozostáva z vybraných l'udí, ktorí zložili prísahu, a ich úlohou je, aby prišli, ked' farár zvolá konvent a múdro rokovali o všetkom, čo prispieva pokroku a rozkvetu farnosti.

\section{Vnútorný, mravnonáboženský stav zboru}

Kostol usilovne navštevujú, častejšie v zimnom, ako v letnom období. Nedel'u prácou vel'mi málo zneuctievajú a počas sviatkov každému, kto sa ocitne v krčme, dedinský richtár po služobnej povinnosti rozkazuje, aby išiel domov, ako i mládeži, ktorá sa po večernej tme zjaví vonku. Verejných protivníkov kultu Božieho niet. A aj tých l'ahostajných voči Večeri Pánovej niet. Okrem málopočetných starších osôb, všetci ostatní sú gramotní a vynachádzajú sa v cirkevnej literatúre a v knihách.

Deti do školy radi posielajú. $\mathrm{V}$ minulom školskom roku školu navštevovalo 257 detí. Knihy, nielen tie cirkevné, ale aj iné, kupujú. 0 tom svedčí aj fakt, že v 100 exemplároch donesená čítanka autora Kollára ${ }^{34}$ je už predaná v 40 exemplároch.

Veriaci sú slušní, vychovaní a vlúdni. Ale sú aj takí, ktorí holdujú alkoholu. Za posledných 15 rokov bolo narodené iba jedno nemanželské diet'a. ${ }^{35}$

${ }^{34}$ KOLLÁR, Ján: Čjtanka anebo kniha $k$ Čjtánj pro mládež we sskolách slowenských $w$ městech a w dědinách. W Budíne 1825.

35 Prekvapivo nízka miera narodenia nemanželských detí nebola neobvyklá ani v iných slovenských cirkevných zboroch. V kánonických vizitáciách z roku 1835 sa uvádza počet mimomanželských detí v rôznych časových intervaloch. Uvádza sa, že v Kovačici sa na 2160 príslušníkov slovenského evanjelického cirkevného zboru v roku 1834 narodili dve mimomanželské deti, kým v Selenči (na 1149 duší), v Padine (na 2525 duší) a v Aradáči (na 1835 duší) ani jedno nemanželské diet'a. V matkocirkvi Hložany, ktorá v roku vizitácie mala 1537 príslušníkov, mimomanželské deti za posledné štyri roky neboli, v Srieme jedno (sem patrili obce: Čerević, Banoštor, Grabar, Sviloš, Susek, Neštin, Ilok a mali úhrnne 247 duší) a roku 1835 sa jedno narodilo aj v Palanke (z úhrnného počtu 311 duší). V Bajši bolo v roku vizitácie 1245 duší a v poslednom desat'ročí sa narodili štyri mimomanželské deti. V Kulpíne, ktorý mal pri poslednom súpise 1110 duší, sa za posledné tri roky narodilo iba jedno mimomanželské diet’a. V Petrovci, v ktorom v roku vizitácie bolo 5031 duší patriacich slovenskému evanjelickému cirkevnému zboru, neuvádza sa počet nemanželských detí, iba pripomienka, že sa také zriedka rodia. V Laliti (na 880 dúš) a v Pivnici (na 1635 duší) mimomanželské deti v roku 1835 nie sú. Najväčší počet nemanželských detí sa vyskytol v Starej Pazove na Vojenskej hranici, ktorá počítala 2631 duší v čase konania vizitácie: z 1745 pôrodov bolo 15 mimomanželských detí a to s cudzincami - no neuvádza sa o aký časový interval ide. (Protocolla visitationis Ecclesiarum E[van]g[e]licarum Bacs-Sirmiensium, instituta anno 1835, mensibus Septembri et Octobri. (EOL - Evangélikus Országos Levéltár, Budapest. Dostupné na: https://library.hungarica na.hu/en/view/Banyai_04_1835_Bacs_Szerem/?pg=123\&layout=s) [prístup 23. 8. 2020]. 
Voči tým, ktorí sú verejní hriešnici, uplatňuje sa zákon Christi Math XVIII, ale civilný magistrát zriedkakedy má do činenia s takými.

Boli dva prípady arbitrárneho rozvodu manželstva.

Vo verejných väzniciach z Kysáča nie je nikto.

Poverčivých niet.

Dobrovol'né príspevky radi dávajú.

IV. Prvý kňaz v Kysáči bol Michal Slamay, ${ }^{36}$ od roku 1788 do roku 1794, ked' pre svoje neskrotné správanie sa, ktoré vôbec nesvedčí kňazovi („statočnost' pera však nedovol'uje obširnejšie sa o tom zmieňovat"), vyhnaný bol do Bajše.

Druhý kňaz prišiel legálne pozvaný roku 1794 z cirkvi v Slovenskej Stamore - ctihodný pán František Jesenský, ${ }^{37}$ muž za cirkev v Kysáči

${ }^{36}$ Pavel Michal Slamay narodený v Slovenskom Pravne alebo v Mošovciach. Bol prvým učitel'om v Starej Pazove, odkial' prišiel do Kysáča za farára 16. marca 1788. Odtial'to 25. júla 1793 odišiel do Bajše, kde bol farárom do roku 1803. Nakoniec sa stal farárom v Mokrej, kde náhle umrel. Szlamay bol mužom vel'mi nepokojného charakteru, s ktorým mal seniorát vel'ké problémy (BIERBRUNNER, Gustáv: A Bács-szerémi ág. hitv. ev. egyházmegye monográfiája az egyházmegye megbízásából összeállítottá. Újvidéken. Ivkovics György könyvnyomdája 1902, s. 77, 105). O ňom podrobnejšie písal František Jesenský, druhý kysáčsky farár vo svoje kronike, tiež Maliak (MALIAK, Jozef: Kysáč. In: Národný kalendár. Zost. S. Štarke, Petrovec : Kníhtlačiareň úč. spol., 1925, s. 41 - 50) a O. Marčok (MARČOK, Ondrej: Z dejín slovenského evanjelického a. v. cirkevného zboru v Kysáči. In: Kysáč 1773 - 2013: zborník prác (Vladimír Valentík, ed.). Báčsky Petrovec : Slovenské vydavatel'ské centrum, Matica slovenská v Srbsku; Kysáč : Rada Miestneho spoločenstva, 2013, s. 239).

${ }^{37}$ František Jesenský (3. apríl 1764 - 11. november 1805) pochádzal zo zemianskej rodiny z Vel'kého Jasena v turčianskej župe. Školil sa v Necpaloch, v Prietrži, v Šajó-Gemeri a v Bratislave. Po ukončení bohosloveckého štúdia ho hned’ roku 1786 povolali za farára do Bardáňa. Čoskoro sa obyvatel'stvo Bardáňa kvôli t'ažkým pomerom (povodne, súdne spory a nespravodlivost' zemepánov) odst'ahovávalo a vel'ká čast' cirkevníkov sa spolu s farárom Františkom Jesenským prest'ahovala do Ečky. Roku 1792 prijal pozvanie cirkevného zboru zo Slovenskej Stamory. Tu ho čoskoro prepadli zlodeji, pričom ho zranili a oslepol na pravé oko, takže si na seniorálnom konvente žiadal službu na pokojnejšom mieste. Na konci roku 1793 prijal pozvanie cirkevného zboru v Kysáči za farára, kde bol 16. marca 1794 uvedený do úradu. Počas jeho pôsobenia v Kysáči bol vystavaný chrám, veža, škola a fara (ČAPLOVIČ, J.: Dejiny slovenského evanjelického a. v. cirkevného sboru, 1928, s. 31, 55). Jeho nástupca Michal Laukonides v Pamätnici zapísal, že F. Jesenský v novembri roku 1805 viezol syna Samuela do latinskej školy do Pol'ného Berinčoka, ochorel a zomrel od zhubnej horúčky. Pochovaný bol 11. novembra 1805 (JESENSKÝ, František: Pamätnica historických zápisov, starších a novších, o povstaní a d'alšom zvel'ad'ovaní cirkvi, počnúc od r. 1773. Archív SECAV, Kysáč). V matrike pochovaných sa uvádza horespomenutý dátum pohrebu, nie deň úmrtia, ani príčina, iba pripomienka, že F. Jesenský umrel ako 37-ročný. Pochovával ho Juraj Ribay, toržiansky farár (Archív SECAV, Kysáč: Matricula Baptisatorum Copulatorum Mortuorum Ecclia Evang. A. C. Addicty. Kisáč ab Anno 1787). V literatúre sa rôzne uvádza deň narodenia F. Jesenského. Ondrej Marčok tento dátum uvádza ako 14. apríl 1765 a deň úmrtia ako 8. november 1805 (MARČOK, O.: Z dejín slovenského evanjelického a. v. cirkevného zboru, s. 239). 
vel'mi zaslúžilý. Najprv bol dekanom Velebného seniorátu Báčskosriemskeho a potom aj notárom. Počas služby tohto správcu, vystavaný je chrám s vežou, kúpené sú dva väčšie zvony, určený je a renovovaný dom pre potreby učitel'a, nová, vel'mi pekná, budova fary; vel'mi starostlivo prepísané mnohé cirkevné protokoly. Umrel mladý 11 . novembra roku 1805.

Tretí kňaz bol ctihodný pán Michael Laukonides, ${ }^{38}$ ktorý bol kaplánom u ctihodného pána Hamaliara v Sarvaši. Na pozvanie Kysáčanov prišiel 29. februára roku 1806. Aj tento muž svojou usilovnost'ou vel'mi prispel k rozkvetu cirkvi, lebo počas jeho služby bola vystavaná veža roku 1816 a vstavané vežové hodiny. Umrel 28. júna 1827 od apoplexie (mozgovej príhody) ako emeritný senior velebného seniorátu báčskosriemskeho.

Štvrtý kňaz som ja, Juraj Jesenský, ${ }^{39}$ narodený 15. februára 1799 od rodičov otca ctihodného pána Františka Jesenského z Vel'kého Jasena (Jeszenszký de Nagy Jeszen) a Kataríny Fábry v Kysáči. Skončil som školu (Humanioru) v Mezoberényi (Pol'nom Berinčoku) a potom sedem rokov pobudol v Požúne (Bratislave). Ked' som skončil Filozofickoteologické štúdiá roku 1824, toho roku som z tohto lýcea sám znovu odišiel do Nového Vrbasu, kde som zvolený od vznešeného seniorátu báčsko-sriemskeho za profesora Gramatickej školy. Bol som správcom katedry pre chlapcov dva školské roky 1824/25 a 1825/26 a ked' som odišiel z tejto Katedry múz a po prijatí obradu vysvätenia od dôstojného pána Adama Loviča prešiel som do podobnej služby v cirkevnom zbore v Kucure. V Kucure som pobudol rok a pol a po smrti Michaela Laukonidesa som prijal pozvanie Kysáčanov a, chvála Bohu, v Kysáči už osem rokov vykonávam kňazskú službu.

Okrem latinského jazyka, ešte viem po slovensky, po nemecky, po srbsky, po rumunsky a po mad'arsky.

A. Povinnost' vedenia cirkevnej služby

1. Kázne sa píšu.

V kázňach sa poslucháči vyzývajú $\mathrm{k}$ poslušnosti voči vládcovi a vrchnosti.

2. Katechizácie letné - od prvej nedele Svätej Trojice až do 6. decembra (podl'a Herdera) sa konajú, ale príliš neriadne dochádzajú,

\footnotetext{
${ }^{38}$ Michal Laukonides (1775 Tó Gyork, Peštianska župa - 1827 Kysáč). Bol kaplánom v Sarvaši, skadial' ho povolali Kysáčania, inštalovaný bol 2. marca 1806. Bol seniorom Báčsko-sriemskeho seniorátu. Počas jeho pôsobenia v Kysáči po jeho boku ako kaplán pôsobil Juraj Hlaváč, neskoršie kucurský farár (MARČOK, O.: Z dejín slovenského evanjelického a. v. cirkevného zboru, s. 239).

${ }^{39}$ Dátum úmrtia: 3. február 1864 (MARČOK, O.: Z dejín slovenského evanjelického a. v. cirkevného zboru, s. 239).
} 
zvlášt' tohto roku. Konfirmandi sa počas štyridsat'dňového pôstu pripravujú na konfirmáciu a na Zelený štvrtok sviatočne prijímajú spoved'. Už osem rokov sa praktizuje inštitúcia mladých manželských párov (mladomanželov) aby sa to, čo je zanedbané súkromne, kompenzovalo vo farnosti inštitucionálne.

3. Obrad nedel'nej bohoslužby sa odbavuje podl'a Rituálu t. j. podl'a zaužívanej obyčaje slovenských evanjelických cirkevných zborov vznešeného seniorátu; v bohoslužbe sa nič nepridáva ani nevyníma. Každodenný obrad odbavujú čítaním textov.

4. Novorodenci sa krstia verejne počas modlitieb v prítomnosti l'udu alebo v iných dňoch. Svätá Večera Pánova sa prisluhuje na sviatok Nového roka - na Vianoce, na Vel'kú noc, na Turíce, na Svätého Jána, na Svätého Michala a štyri alebo pät' nediel' podl'a dohody/potreby veriacich.

5. Chorým sa poskytuje obrad duchovnej a fyzickej podpory. Lekára, ak je potrebné, dovážajú a ak sa odporučí, predtým sa dáva vakcína proti osýpkam.

6. Školu navštevujem často a bez oznámenia, aby som učitel'a povzbudil a aby prijal dobré rady.

7. Hoci ešte nie sú v zrelom veku, podl'a Cisárskeho patentu, po troch vykonaných ohláškach a po skladaní prísahy uzavierajú manželstvo. ${ }^{40}$

8. Zosnulých nepochovávajú skôr, ako uplynie 48 hodín, vyjmúc $\mathrm{v}$ dovolených prípadoch.

9. Matriky, protokoly, účty sa pravidelne/úhl'adne vedú.

B. Morálny charakter: Muž málo vzdelaný, ale hrdý. Farár je nedbanlivý a neprístupný. ${ }^{41}$

C. Knižnica: pokrytá prachom. ${ }^{42}$

D. Byt: budova fary vystavaná roku 1806 má tri izby a špajzu; nevyhovujúci, vel'mi sa snažíme dobudovat' vhodnejší.

E. Dôchodok Služobníka Slova Božieho.

1. Fixný: každý manželský pár platí 20 grajciarov v konvencionálnej mene.

2. Tí, ktorí používajú pôdu a majú domy, dávajú jednu tretinu peštianskej merice pšenice. Subinkvilíni polovicu z peštianskej merice pšenice a v peniazoch 20 grajciarov v konvencionálnej mene.

3. Polovicu sesie [mu] spolu s lúkou a záhradou obrábajú veriaci.

4. Štyri vozy sena.

\footnotetext{
${ }^{40}$ Dolná hranica sobášneho veku podl’a vtedajších predpisov bola 18 rokov pre mužov a 16 rokov pre ženy.

41 Čast' písaná kurzívou je v originálnom zdroji písaná iným rukopisom.

42 Čast' písaná kurzívou je v originálnom zdroji písaná iným rukopisom. Naráža sa na nezáujem Služobníka Slova Božieho o používanie kníh.
} 
5. Od uvádzania šestonediel'ky/porodenej ženy 18 grajciarov. k.m.

6. Od sobášu 1 f. k.m., od ohlášky budúcich mladomanželov 10 grajciarov k.m. a od úvodu mladuchy 18 grajciarov k.m., pečené mäso a vína pol. ${ }^{43}$

7. Malý pohreb 18 grajciarov k.m. a vel'ký s kázňou 1 forint. ${ }^{44}$

8. Z peňazí zo spovede šestina patrí učitel'ovi a z trikrát do roka (na sviatky) zbieraných milodarov tretina patrí učitel'ovi.

9. Tretina z koledy patrí učitel'ovi.

10. [Dostáva] šest' siah dreva na kúrenie.

11. Mletie obilnín.

12. Voz pre potreby svätého obradu.

13. Z každej domácnosti kohúta.

Presne a pravidelne podl'a obyčaje platia záväzky, aj viacej, jednu alebo dve siahy dreva. Zmluva poplatkov je zlepšená 19. decembra roku 1833. Pôdu by mohli lepšie obrábat', ohradená je priekopou.

V. Škola.

A. Školský učitel' Samuel Mihalovič má 21 rokov, predtým tri mesiace [pracoval] v Palanke, potom dva roky v Kulpíne a teraz je u nás učitel'om dva mesiace. Školil sa v Novom Vrbasi a v Pol'nom Berinčoku.

a. Mladík má pekné maniere, je vel'mi poslušný.

b. Tohto mesiaca v septembri u nás deti prvýkrát spievali v chóre, čo je vel'ký úspech dosiahnutý v učení. Potrebné je, aby pracoval podl'a Bel Lankasterovej metódy, 45 aby sa zväčšil počet žiakov.

B. Počet žiakov v školskom roku 1834/35, ktorí navštevovali školu 257.

C. Deti do 12 rokov v Kysáči navštevujú školu, školský rok sa začína 1. septembra a končí sa v júni.

c. Vyučujúce predmety: okrem čítania, písania, spievania, katechizmu, majú aj fyziku, prírodné vedy, prírodopis, zemepis, zdravotný katechizmus, biblickú históriu a aritmetiku.

d. Okrem mnohých iných učebníc používajú aj Čítanku.

D. Školská budova spolu s bytom učitel'a je dostatočne priestranná.

E. príjem/plat učitel’a je nasledujúci:

\footnotetext{
${ }^{43}$ Neuvádza sa miera.

${ }^{44}$ Pod malým pohrebom sa rozumie pochovávanie mladších alebo tých, ktorí nie sú konfirmovaní. Takí sa pochovávali bez kázne.

45 Táto organizačná forma vyučovania vznikla na sklonku 18. storočia, ked' nezávisle jeden od druhého anglikánsky farár Andrew Bell (1773 - 1832) a učitel' Josef Lancaster (1771 - 1838) počnúc rokom 1798 vo svojej práci zapájali starších žiakov do vyučovania tak, že pomáhali učitel'ovi pri vyučovaní mladších spolužiakov (Potkonjak - Šimleša, 1989: 47).
} 
1. fixný - od manželského pára dostáva 15 grajciarov v peniazoch a polovicu tzv. veky ${ }^{46}$ (v obilninách) od tých, ktorí vlastnia pôdu a ktorí majú dom. A od subinkvilínov iba šiestu čiastku peštianskej merice alebo l'udovo povedané - porciu podl'a peštianskej merice.

2. Štvrtinu sesie, ktorú obrábajú veriaci a taktiež záhradu.

3. Dve siahy dubového dreva na kúrenie.

4. Od každého diet'ata'a, ktoré chodí do školy, dostáva 15 grajciarov viedenskej meny.

5. Pasenie dobytka, ${ }^{47}$ mletie múky a pohostenie.

6. Od malého pohrebu 18 gr. viedenskej meny a od vel'kého so spievaním 30 gr.

7. Podl'a potreby voz.

8. Mletie obilnín pre domáce potreby.

9. Od darov na tri sviatky každoročne má tretinu.

10. Má od dávok konfirmandov.

11. Od koledy tretinu.

Plat učitel'ovi sa dost' nepravidelne platí.

F. Škola má také fondácie ako cirkev.

G. Inšpektor školy je miestny farár.

H. Školské učebnice: Hübnerove Dejiny, Biblia s Novým zákonom, Tranoscius 2 exempláre, Čítanka.

I. Vážený pán dekan obyčajne navrhuje a určuje sériu lekcií alebo predmetov, ktoré sa majú vyučovat'.

VI. Dve babice, ${ }^{48}$ ktoré zložili prísahu, vedia formulu krstu, podporujú sa vo vykonávaní povinností. Dostávajú plat jeden chlieb a 6 grošov viedenskej meny po jednom pôrode.

VII. Hrobár je súčasne aj zvonár, býva v byte, ktorý cirkev vybudovala a oslobodený je od všetkých poplatkov. Kope jamy zodpovedajúcej hĺbky, jeho plat vynáša 19 peštianskych meríc obilnín a od každého manželského pára groš. Mŕtvi novorodenci sa pochovávajú na cintoríne. Tiež aj samovrahovia, ktorí pre chorobu (nech im Pán Boh odpustí) spáchali samovraždu.

VIII. Nemajú nijakú charitatívnu ustanovizeň, nemajú ani dom pre vdovcov farárov a učitel'ov.

IX. Ročné spovede

Po eucharistii býva kázeň. Vo vianočnej kázni sa spomína aj vládca. V nedel'u po prvom novembri kázeň a inaugurácia richtára a prísažných.

\footnotetext{
${ }^{46}$ Veka - štvrtina peštianskej merice.

${ }^{47}$ Právo pasenia svojho dobytka na obecnom pastvisku.

${ }^{48}$ Dnes pôrodné asistentky.
} 
X. Žaloby a obvinenia

1. Zo strany cirkvi.

2. Zo strany farára - komfortnejší byt si želám.

3. Zo strany učitel'a: aby sa plat pre vyučovanie zmenil na fixný.

XI. Navrhuje sa, aby sa zrušilo pre zneužívanie:

1. Nočná služba na sviatok narodenia Ježiša Krista sa nemá nepraktizovat'.

2. Aby sa prestalo s bezuzdnými zábavami (bakchanáliami) v nasledovné tri dni, čo aj skôr bolo zrušené.

3. Oblievačky na Vel'kú noc! Beda! Vel'mi rozšírené.

4. Veselé a bohaté zábavy na deň cirkvi sa u nás vel'mi málo praktizujú.

5. Hostiny (slávnostné obedy) po krstinách sú vel'mi rozšírené, svadby trvajú aj štyri dni, kar (pohrebná hostina pre zosnulých) sa taktiež praktizuje.

6. Kázne na pohrebe sa praktizujú pre tých, ktorí už prijali konfirmáciu alebo prijali Večeru Pánovu. Praktizuje sa prenášanie zosnulého v pokrytej truhle.

Zapísal Juraj Jesenský cirkvi A.V. kysáčskej Služobník Slova Božieho, 30. septembra roku 1835.

30. septembra roku 1835 vykonaná je kánonická vizitácia evanjelickej cirkvi v Kysáči. Vykonali ju superintendent ${ }^{49}$ Banského dištriktu dôstojný Pán Ján Seberíny v prítomnosti vznešeného seniora Jána Stehlu a čestných pánov Daniela Kolényiho, Jána Rohonyiho, Ludvika Muskuliho a Jána Škultétyho zapisovatel’a a váženého pána prísediaceho konventu Martina Martonfiho, zapísali nasledujúce o tej kánonickej vizitácii:

1. Aby sa o mladých konfirmandoch, aj mládencoch, aj dievkach, v budúcnosti svedomitejšie staralo. Pre túto aktivitu Služobníkovi Slova Božieho sa ako vzor odporúča Herderov Katechizmus.

2. Na strieborný kalich sa má zaobstarat' nápis cirkvi s uvedením roku kúpy a pre chorých sa má kúpit’ malý kalich.

3. Oblátky sa majú pripravovat' z múky najlepšej kvality.

4. Kovová krabica sa má čistejšie udržiavat' alebo sa má zaobstarat' iná, z postriebreného olova.

5. Taktiež sa majú zadovážit' nové konvice z postriebreného olova pre držanie vína.

6. Biblia a dva doslúžilé protokoly sa majú dat' do novej tvrdej väzby.

\footnotetext{
${ }^{49}$ Roku 1883 je titul superintendent nahradený titulom biskup (PETRÍK, B. - RYBÁR, P. (eds.): Evanjelická encyklopédia Slovenska, s. 354).
} 
7. Veriaci sa majú vyzvat', aby sa zdržali od spievania na Vianoce pod oknami a v čase Vel'kej noci celkom zakázat' oblievačky.

8. Na hostinách po krstinách, uzavretí manželstiev a na karoch odporúča sa striedmost'.

9. Ked' vizitácia bola vykonaná, v prítomnosti mnohých, ktorí účinkovali vo vizitácii, dôstojný pán superintendent vyjadril vel'kú l'útost' preto, že cirkev nenašiel v zodpovedajúcom stave, tak ako by bolo treba, na prvom mieste zanedbané je učenie mládeži v krest’anskej vierovede. Tiež sme zistili, že súčasný kňaz službu neslušne, provokujúco vykonával.

V Kysáči, dňa 30. septembra roku 1835

Ján Stehlo, senior báčsko-sriemsky

Ján Škultety, notár Báčko-sremskeho seniorátu a súčasne notár tejto kánonickej vizitácie

Ján Seberíny, superintendent»

Zápisnica o kánonickej vizitácii evanjelického a. v. cirkevného zboru v Kysáči z roku 1835 má ako primárny zdroj mimoriadny význam pre dejiny tohto cirkevného spoločenstva a Slovákov v Kysáči, ale i širšom kontexte v dejinách Slovákov v južnom Uhorsku (na Dolnej zemi), pretože ponúka množstvo nových údajov, ktoré sa predovšetkým vzt'ahujú na cirkevný a školský život tohto náboženského a národnostného spoločenstva.

V Zápisnici sú aj iné údaje relevantné pre spoločenské a historické dejiny, ktoré by v značnej miere mohli prispiet' $\mathrm{k}$ všestrannejšiemu osvetleniu spoločenského a hospodárskeho života Slovákov v Kysáči a na Dolnej zemi od konca 18. do polovice 19. storočia, v období, ktoré je doposial' nedostatočne preskúmané.

Ked'že kánonická vizitácia prebehla štyri roky po prvej cholerovej epidémii v Báčke, dalo by sa očakávat', že budú zaznamenané nejaké poznámky, napr. vo forme pohrebov, prípadne osobitného cintorína. Podl'a údajov v matrike zomrelých sa však dá usúdit', že cholera roku 1831 Kysáč obišla. ${ }^{50}$

\footnotetext{
${ }^{50}$ Prvý prípad cholery bol zaznamenaný 23. septembra roku 1831, podlahol jej 27-ročný Martin Dobrovský. V októbri bolo 13 úmrtí, v novembri jedno a 17. decembra roku 1831 bol poslednou obet'ou cholery 39-ročný Jozef Gašpar. V tomto roku umrelo 154 obyvatel'ov Kysáča (75 mužského a 79 ženského pohlavia), takže 16 prípadov úmrtia na choleru sa môže považovat' za ojedinelé prípady a nie za epidémiu. V Báčke bola zaznamenaná druhá vlna cholery roku 1836. Hoci sa v kysáčskej matrike pochovaných počas celého roka neuvádza príčina smrti zosnulých, podl'a zaznemenaného vel'kého počtu pochovaných $\mathrm{v}$ auguste a v septembri predpokladáme, že išlo o choleru (počet pochovaných $\mathrm{v}$ januári bol 8 , vo februári 8 , v marci 7 , v apríli 4 , v máji 3 , v júni 3 , v júli 3 , v auguste $42, v$
} 


$$
\text { Janko Ramač - Daniela Marčoková }
$$

Konštatujeme, že podrobná analýza a publikovanie d'alších zápisníc kánonických vizitácií z iných vojvodinských obcí, v ktorých žili, resp. žijú Slováci vo väčšom počte by zodpovedala stanovenému ciel'u práce. Zápisnice sú bohatým zdrojom údajov dôležitých pre doplnenie obrazu vypovedajúceho o minulosti tohto národnostného spoločenstva. 